\title{
Value of Computed Tomography Scan to Evaluate the Radio Capitellar joint in Monteggia type IV lesion
}

\author{
Ricardo Monreal $^{1 *}$ and Giovanni Osinaga ${ }^{2}$ \\ ${ }^{1}$ Medica Vial, Orthopedic Clinic. Alvaro Obregon No.151, Mexico \\ ${ }^{2}$ Department of Orthopaedics, Hospital Obrero No. 3, Caja Nacional de Salud, Bolivia
}

Submission: March 02, 2020; Published: April 03, 2020

*Corresponding author: Ricardo Monreal, Medica Vial, Orthopedic Clinic. Alvaro Obregon No.151, Col. Roma Norte, Zip Code 06700, Mexico City, Mexico

Abstract

In Monteggia type IV injury, the radio capitellar joint should be examined carefully. Failure to recognize an associated radial head fracture dislocation may lead to problems with preoperative planning for additional procedures involving the radial head and computed tomography (CT) scan is an important tool to identify such undiagnosed injury.

Keywords: Monteggia lesion; Radial head dislocation; Classification; Elbow fracture; Computed Tomography, Computed tomography scan

\section{Introduction}

Fractures of both radius and ulna are one of the most common fractures in adults in upper extremity [1]. Fracture of both forearm bones associated with radial head dislocation is considered a Monteggia fracture-dislocation type. One case of Monteggia equivalent (posterolateral fracture dislocation of the radial head) lesion is presented and discussed.

\section{Case Report}

A 32-year-old male patient after sustained a fall presented a deformity in the left forearm and painful limited range of motion. X-rays showed a displaced diaphyseal ulna and radius fracture with posterolateral radial head dislocation (Figure 1) and additional information was obtained by computed tomography showing a marginal fracture of the radial head (Figure 2). Under general anaesthesia the ulna and radius diaphysis were fixed with a 3.5mm locked compressive plate (LCP) and osteosynthesis of the radial head fracture was performed with four interfragmentary screws (Figure 3).

\section{Discussion}

Monteggia`s lesions are complex fractures of the forearm. In 1967 Bado [2] described the full spectrum of Monteggia`s lesion including four different types and it became the universally accepted classification.

In types I-III of Bado's classification, the fractures of the ulna are associated with the dislocation of the proximal radio ulnar joint; in contrast, Type IV is characterized by fracture of both forearm bones with anterior dislocation of the radial head. Bhandari \& Jindal [3] reported a type IV case with posterolateral dislocation of the radial head, so they suggested subgroups of Monteggia type IV injury according the direction of the radial head dislocation: Type IV-A lesion the fractures of the radius and ulna are associated with anterior dislocation of the radial head, type IV-B with posterior dislocation, type IV-C with lateral dislocation and type IV-D there is a combination of types IV-A with IV-C or IV-B with IV-C.

In this patient, X-rays showed a displaced diaphyseal ulna and radius fracture with posterolateral radial head dislocation (Figure 1) but additional information was obtained by computed tomography showing a marginal fracture of the radial head (Figure 2). When fracture of both forearm bones is associated with dislocation of the radial head (Monteggia type IV lesion and its variants), the radio capitellar joint should be examined carefully by computed tomography (CT) scan to rule out a fracture of the radial head. 


\section{Orthopedics and Rheumatology Open Access Journal (OROAJ)}

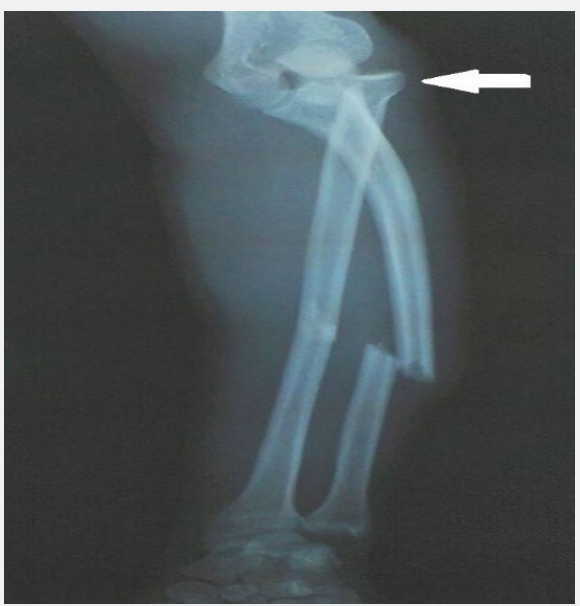

Figure 1: Radiograph shows a displaced midshaft ulna and radius fracture with posterolateral radial head dislocation fracture without radiological evidence of radial head fracture (withe arrow).

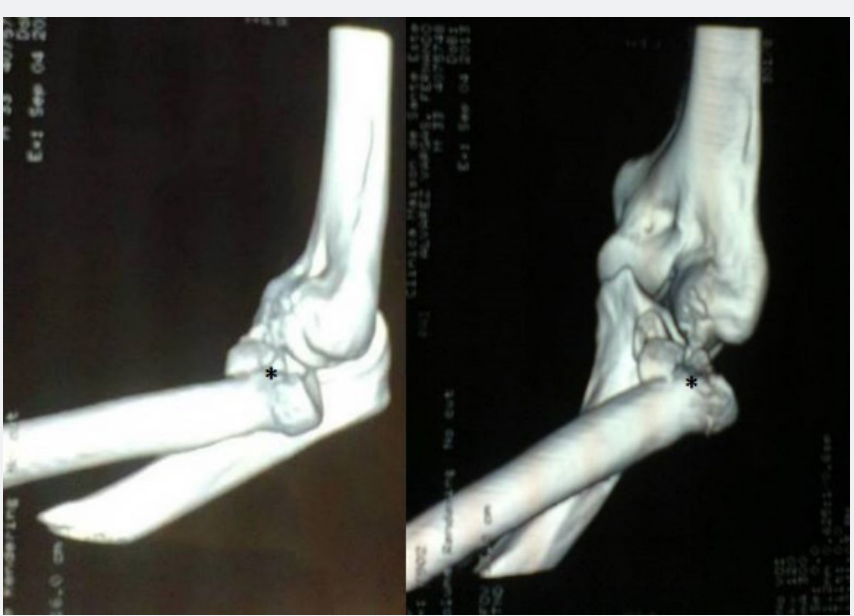

Figure 2: Computed Tomography (CT) shows a marginal fracture of the radial head (asterisk).

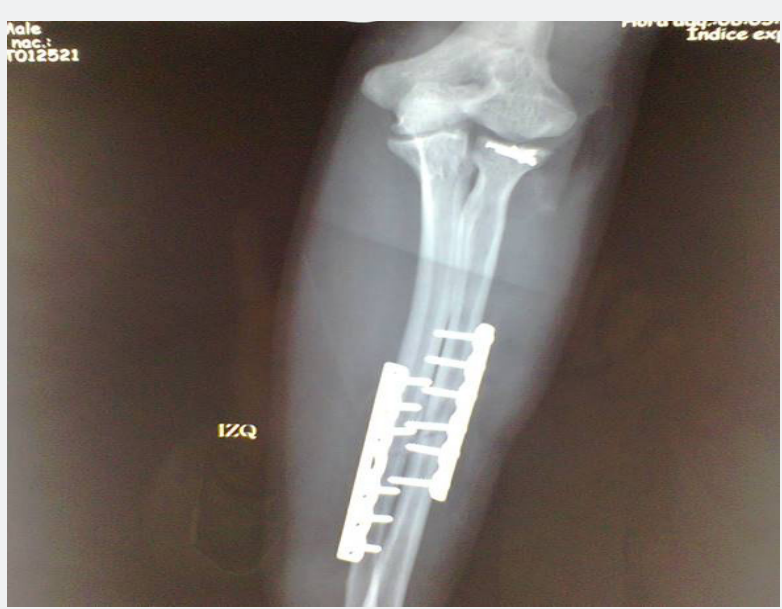

Figure 3: X-ray shows both forearm bones fixed with a 3.5mm locked compressive plate (LCP) and osteosynthesis of the radial head fracture performed with four interfragmentary screws. 


\section{Conclusion}

The early diagnosis of a radial head fracture-dislocation is the key to treat these injuries. It is possible that in the preoperative radiographs the radial head fracture was not evident and the computed tomography (CT) scan identified such undiagnosed injury. Failure to recognize an associated radial head fracture dislocation may lead to problems with preoperative planning for additional procedures involving the radial head.

\section{Compliance with ethical standards}

\section{Conflict of interest}

Author declares no conflict of interest.

\section{Funding}

There is no funding source.

\section{References}

1. Al-Sadek, Niklev D, Al-Sadek A, et al. (2016) Diaphyseal Fractures of the Forearm in Adults, Plating or Intramedullary Nailing?. Open Access Maced J Med Sci 4(4): 670-673.

2. Bado JL (1967) The Monteggia lesion. Clin Orthop Relat Res 50: 71-86.

3. Bhandari N, Jindal P (1996) Monteggia lesion in a child: variant of a Bado type-IV lesion. A case reports. J Bone Joint Surg Am 78(8): 12521255.

\section{Your next submission with Juniper Publishers will reach you the below assets}

- Quality Editorial service

- Swift Peer Review

- Reprints availability

- E-prints Service

- Manuscript Podcast for convenient understanding

- Global attainment for your research

- Manuscript accessibility in different formats ( Pdf, E-pub, Full Text, Audio)

- Unceasing customer service

Track the below URL for one-step submission https://juniperpublishers.com/online-submission.php 